DOI: 10.2478/aussoc-2019-0007

\title{
The Discreet (and Long-Lasting) Charm of the Polish Nobility
}

Rafał Smoczyński and Tomasz Zarycki: Totem nteligencki. Arystokracja, szlachta i ziemiaństwo w polskiej przestrzeni społecznej (The Intelligentsia's Totem. Aristocracy, Nobility, and Landed Gentry in the Polish Social Space) Warsaw: Wydawnictwo Naukowe Scholar, 2017. 303 pp.

\author{
Andrzej TURKOWSKI \\ Robert B. Zajonc Institute for Social Studies, University of Warsaw \\ andrzej.turkowski@student.uw.edu.pl
}

Elite studies, which would be both critical (in a sense that they do not reproduce self-images created by actors under study) and at the same time rely on substantial empirical material "from within", are perhaps the hardest job to do for a sociologist. It seems (at least to a Pole) that this is even more so in the case of Poland, where the relations within the intelligentsia élite milieu are even more informal (thus prone to being hidden from the wider public) than in many other European countries - as one can learn it from other works of one of the authors of the reviewed book, Tomasz Zarycki. Despite numerous obstacles, Smoczyński and Zarycki made a successful attempt at analyzing an important part of the Polish field of power (Bourdieu 1993: 161-175, 1996: 261-339) of the aristocracy, nobility, and landed gentry.

Although at the empirical core of the book there lies an analysis of social structure and mechanisms of reproduction of a small group ("several dozen post-aristocratic families”), the perspective of Pierre Bourdieu's field analysis, which the authors adopted among other theoretical inspirations, required them to broaden the scope of the study. Thus, the book includes both a historical and "spatial" (relations with other social groups) context. As a result, the volume presents a valuable insight not only into the functioning of a small but relatively influential aristocratic sub-élite but also - by analyzing its relationship with the intelligentsia - into this hegemonic social class in Poland.

As has been already mentioned, the main focus of the book is on the aristocratic/ post-gentry milieu in contemporary Poland. The first chapter though is dedicated 
to discussing the historical developments concerning Polish nobility. The main thesis here concerns a rivalry for hegemony between aristocracy/gentry and intelligentsia - two social classes which, to a certain degree, are overlapping while relying on different types of capital (economic versus cultural capital) -, which ended up with the victory of the latter. The decisive moments in this process were the Bolshevik revolution, the Polish-Soviet war, and the Treaty of Riga, which established borders and acknowledged the loss of significant portion of the Polish gentry's demesnes. All these three events could be seen as final blows to the landed gentry - thus far from holding the dominant position. After establishing the Second Republic of Poland, which the authors dubbed as the "republic of the intelligentsia", the weakened aristocracy and gentry have started, gradually, to take on the role of an internal sub-élite of the intelligentsia.

The analysis of the contemporary field of nobility in Poland - based on 82 indepth interviews conducted by the authors - is presented in the third chapter. According to the authors, this social space can be seen as located between two poles: on the one hand, there is an informal part, composed primarily of several dozen post-aristocratic and gentry families fostering dense family ties; on the other hand, there are the descendants of landed gentry, cultivating their noble heritage through the formal non-governmental organizations. It is this first group, informal and largely hidden to the public - the "extended family" -, to which the authors assign the role of the main collective actor, which refers to the legacy of nobility in contemporary Poland. In contrast to the second group, whose members' "noble identity" is rather a matter of reconstruction (and thus needs to be re-affirmed through the abovementioned formal organization), the "extended family" represents a residue of aristocratic clan family structures. The fact that this kind of family structure has survived seems indeed extraordinary, given the drastic changes the Polish society has gone through over the course of a turbulent $20^{\text {th }}$ century.

Smoczyński and Zarycki's anthropological analysis includes a description of the informal structure of this hermetic social network based on social and cultural capital as well as of the mechanisms of its reproduction. Here, the main characteristic feature is the cultivation of family ties between distant relatives through numerous family rituals such as weddings, funerals, holiday meetings, or joint holiday trips. These dense relations enable the "extended family" to create space for effective matrimonial, social, and ideological games which, in turn, create a sufficiently strong social basis to uphold their noble identity.

Although the identification and analysis of the "extended family" and of the broader Polish field of nobility is in itself an impressive sociological achievement, even further-reaching is Smoczyński and Zarycki's attempt to use the history of nobility (in particular its last stages) to re-interpret much of the key moments of the Polish social history. Of crucial importance here is the abovementioned historical analysis of a rivalry between nobility/landed gentry and the intelligentsia, which 
was won by the cultural capital-based part of the Polish élite. Inspired by Maria Ossowska's argument about the adaptation of part of the aristocratic ethos by the triumphant French bourgeoisie, in the aftermath of the 1789 French Revolution (Ossowska 1985), Smoczyński and Zarycki argue that a similar process took part in the case of Poland.

The chapters IV-VII. of their book are dedicated to the analysis of the hybrid model of Polish citizenship, which, according to authors, contains numerous elements of the gentry ethos. Through an analysis of the attitudes of a wider society (students in chapter four and mass media in chapter five) towards the legacy of Polish nobility, the authors show that this heritage still occupies a relatively significant position in contemporary Poland and that the post-feudal framework of interpretation permeates both public life and popular culture. It is thanks to this part of the book that one can better understand the mixture of amusement and respect that some people from Eastern Europe (Belarusians, Russians, or Ukrainians) express when it comes to a widespread and strongly naturalized habit of Poles to address each other per pan/pani (sir/madam).

Finally, in chapter six, Smoczyński and Zarycki lay out their core argument about the origins of the Polish (hybrid) model of citizenship and the influence that the feudal past has exerted on its development. In this context, they argue that in the Second Republic of Poland a symbolic nobilitation was carried out by the intelligentsia, which broadened the citizenship status from nobility/landed gentry to all previously excluded social classes (hence, the abovementioned "pan/ pani” convention). Apart from an explanation of its origins and characterization, the authors provide a brief comparison with other countries, both in Western and Eastern Europe, allowing the reader to better grasp the distinctiveness of the Polish case.

In the last chapter, the narrative is put back on the contemporary Poland as well as on the empirical material. With a usage of the Durkheimian concept of totemism (Durkheim 1995), the authors reveal how the legacy of nobility and gentry (including the living members of the "extended family") is treated by the intelligentsia as "totems": the source of legitimization of the intelligentsia's continuous leadership as well as a reminder of Poland's past glory. Astonishingly, one of the key properties of this "intelligentsia totem" relates to their ability to redefine (improve) status position. This is visible on the example of actors engaged in personal relations with members of aristocracy ("totems"), including through participation in their family rituals.

Smoczyński and Zarycki's argument about the usage of totem for the reproduction of social structures, legitimization as well as day-to-day status games of the intelligentsia is not only highly informative but also provides a tool for the interpretation of the position occupied by some of the key authorities of the Polish élite (Turkowski 2018). 
Overall, the reviewed book, with its numerous insights, fresh and surprising interpretations, and a clearly visible passion to deconstruct the self-images created by the members of the élite, represents a bright spot on the map of Polish élite studies.

\section{References}

Bourdieu, Pierre. 1996. The State Nobility. Elite Schools in the Field of Power. Cambridge: Polity Press.

1993. Field of Power, Literary Field and Habitus. In: P. Bourdieu (ed.), The Field of Cultural Production. Cambridge: Polity Press. 161-175.

Durkheim, Emile. 1995. The Elementary Forms of Religious Life. New York: The Free Press.

Ossowska, Maria. 1985. Moralność mieszczańska. Wrocław: Zakład Narodowy im. Ossolińskich.

Turkowski, Andrzej. 2018. Polish Intelligentsia Totems in Elites' Struggles for Legitimization: The Case of Jerzy Giedroyc and Poland's Eastern Policy. East European Politics and Societies: and Cultures. First published: May 23 (https:// doi.org/10.1177/0888325418764607). 